Fall 9-16-2017

\title{
Can A Leopard Change Its Spots?
}

Mark Y. Herring

Winthrop University, herringm@winthrop.edu

Follow this and additional works at: https://digitalcommons.winthrop.edu/fac_pub

Part of the Arts and Humanities Commons, and the Education Commons

\section{Digital Commons Citation}

Herring, Mark Y., "Can A Leopard Change Its Spots?" (2017). Winthrop Faculty and Staff Publications. 79. https://digitalcommons.winthrop.edu/fac_pub/79

This Article is brought to you for free and open access by Digital Commons @ Winthrop University. It has been accepted for inclusion in Winthrop Faculty and Staff Publications by an authorized administrator of Digital Commons @ Winthrop University. For more information, please contact digitalcommons@mailbox.winthrop.edu. 


\section{V29 \# 4 LITTLE RED HERRINGS - CAN A LEOPARD CHANGE ITS SPOTS?}

Sep 26, 2017

by Mark Y. Herring (Dean of Library Services, Dacus Library, Winthrop University)

At the time of this writing, the single biggest library-related news is Elsevier's acquisition

of bepress [sic]. The move startled information pundits on several counts. First, none of us knew about the deal until it had been done. For whatever reason (a slip between the cup and the lip is certainly one possibility), bepress chose to let us let find out via social media. I saw it first on the Scholarly

Kitchen website (http://bit.ly/2uYXP4Z), and then later on a slew of other social media. The other reason that everything went viral at once proved, of course, to be that bepress, a kind of mom and pop Jedi-shop, sold out to, in the eyes of many librarians, the Darth Vader of vendors, Elsevier.

For decades, bepress did yeoman's work in the world of open access, providing a first-rate software platform for many libraries that could not afford to create one themselves. The cost of said software, while not cheap, was much cheaper than hiring three or four coding librarians to create an open access portal for an institution's intellectual footprint. Those intellectual footprints, now institutional repositories, proved the perfect launching pad for open access content. Add to the first-rate software, first-rate customer service, and you have the formula for its success.

For most of those decades, vendors like Elsevier smiled bemusedly at libraries trying to gain an alternative foothold for expensive subscriptions. In many ways, the efforts of libraries were cute, and vendors like Elsevier patted us on the head and raised prices for key journals another few percentage points. Open access, it appeared, was going nowhere fast, and it did itself no favors with grand missteps like pay-for-play journals, too.

So how did two seemingly disparate companies get together?

In a word, need drove them together, but need of a different sort for both. Although I have no inside information, for bepress, it must have been the need for cash to develop its big plans. It must have been frustrating for bepress to be successful yet remain a small company making a great product. There was so 
much more it could do, but a fair price for a great product just made the going so slow it must have seemed to slog at times. Ambition to make bepress better at everything it did, especially analytics, must have also seemed too appealing to wait. In order to get to that point, bepress would have had to raise prices so high so fast it might well have lost too many customers. The choice was to plod along or look for a Sugar Daddy. Enter sweet Elsevier with deep pockets. Again, although I have no inside information, Elsevier did not get to be one of the largest vendors by ignoring the market. Sure, for about a decade and a half, open access and institutional repositories seemed like two ugly stepchildren with no fairy godmother, destined to live forever in the cinders and ashes. Then suddenly, libraries everywhere of every size began creating IRs with some success. While the content may never rival Elsevier's these idiot stepchildren were making this first-rate content freely available to anyone. Frankly, it was a brilliant move on the part of Elsevier, at least from their perspective. Open access may still fail completely, but for now, a good portion of it is in the hands (some might want to say stranglehold) of a company not really known for its frugality to customers.

Once everything about the bepress acquisition went viral, its spokespersons came out with several statements. First, to apologize for not letting its customers know about the acquisition before it announced to everywhere else. Managing director Jean-Gabriel Bankier rightly apologized for not letting customers know first and committed to communicating better. Probably an apology for not communicating at all would have been better. Frankly, it felt a little like getting to the altar and the spouse-to-be saying, "By the way, I'm already married." Could it have been that bepress knew this was a hornet's nest best not to be kicked by it, but to throw that nest onto the social media highway and deal with the buzz later? Hard to say.

After the sort of esprit d'escalier apology, assurances were made that nothing would change and content would remain our own; bepresswould remain as committed as ever to keeping everything functioning normally, customer service would remain first class, and the pricing structure would remain the same. Furthermore, our content will remain as portable as ever. The key takeaway here is that all of this is true now.

What we do not know is whether Elsevier will begin charging for various portions of the service, such as the dashboard or for reports to users about the use of their content. Will there be a charge after a certain number of submissions, and how quickly, if at all, will prices begin to rise? How soon, if at all, will Elsevier begin replacing bepress employees with their own? In the eyes of many colleagues, keeping things functioning normally after what appears to be a dinner with the devil will take a spoon so long it has not yet been made. 
My only experience with Elsevier is having to pass on many products because it takes so much of our scant resources. The content is fine, of course; it is just the king's ransom we must pay to make Elsevier materials accessible requires us to say no, more often than not.

And that brings us, finally, to the leopard and its spots. Can he change them? I suppose the best answer for now is that there is a first time for everything. Even for Elsevier. 